\title{
THE ROLE OF THE FEDERAL ENERGY REGULATORY COMMISSION IN AUTHORIZING HYDROKINETIC TECHNOLOGY PROJECTS
}

BY TIMOTHY KONNERT

ABSTRACT. There is growing interest in hydrokinetic technologies used to harness the free-flowing, renewable energy of the ocean's waves, currents, and tides, as well as inland rivers, without the use of dams. In response to this growing interest, the Federal Energy Regulatory Commission has experienced a surge in activity regarding the testing and development of hydrokinetic projects. Although the Commission's well-tested regulatory process is compatible with these hydrokinetic projects, providing a strong foundation for overseeing their orderly development, the Commission has been taking steps to adapt its program to the challenges of a new technology. Using input actively solicited from the industry, state and federal agencies, Native American tribes, and the public, the Commission has adapted its administrative procedures to meet the challenges of regulating this nascent industry.

\section{FEDERAL ENERGY}

\section{REGULATORY COMMISSION}

The Federal Energy Regulatory

Commission (hereafter FERC or

Commission) is an independent agency that regulates the siting of natural gas and hydropower projects as well as the rates, terms, and conditions of the interstate transmission of natural gas, oil, and electricity. The Commission is composed of up to five commissioners, each of whom has an equal vote on regulatory matters. The commissioners are appointed to five-year terms by the President of the United States with the advice and consent of the Senate, with one member designated by the President to serve as Chair and administrative head. No more than three commissioners may belong to the same political party, the President and Congress do not review decisions, and funding is provided from fees paid by, and annual charges to, the regulated industries.
HYDROKINETIC TECHNOLOGIES Interest is growing in new technologies used to harness the energy of the ocean's waves, currents, and tides, as well as the flows of inland rivers, without the use of dams. These technologies are commonly referred to as "hydrokinetic" based on the language of the Energy Independence and Security Act of 2007. Hydrokinetic technologies have significant potential, with the potential for wave and current power estimated to be approximately 429 terawatt hours per year, more than double current hydropower production (Bedard et al., 2009). The Commission anticipates further exploration of these technologies in order to understand the amount of

Timothy Konnert (timothy.konnert@ ferc.gov) is Fish Biologist, Federal Energy Regulatory Commission, Division of Hydropower Licensing, Washington, DC, USA. 
energy that can be developed, its reliability, environmental and safety implications, and its commercial viability.

\section{HYDROPOWER PROGRAM}

The Commission's hydropower program consists of the licensing, license compliance monitoring, and safety inspection of jurisdictional nonfederal hydropower projects. Commission staff working with the hydropower program includes engineers, biologists, cultural and recreation specialists, attorneys, and others who help the Commission conduct and make decisions in hydropower proceedings.

\section{Jurisdictional Authority}

The Commission has broad authority to issue licenses for hydroelectric projects, as set forth in Section 4(e) of the Federal Power Act (FPA). Projects that are required to be licensed, as set forth in Section 23(b)(1) of the FPA, include all nonfederal hydropower projects that are located in navigable waters or upon federal lands or reservations of the United States, that use water from a government dam, or that are located in waters over which Congress has jurisdiction, involve post-1935 construction, and affect interstate commerce by being connected to, or displacing power from, the interstate power grid. Although the Commission has historically dealt primarily with conventional hydropower projects located at dams within riverine systems, new hydrokinetic technologies fall under the Commission's jurisdictional authority as well.

In October 2002, the Commission issued an order finding the Makah Bay Wave Energy Project, proposed to be located off the coast of the State of Washington, to be within its jurisdiction and required the project to obtain a license for construction and operation (101 FERC 62,009). The Makah Bay Project was designed to harness wave energy through an array of buoys connected to a transmission cable carrying power to an onshore station. On December 21, 2007, the Commission issued an original license for the Makah Bay Project, the first FERC license issued for a hydrokinetic technology project (121 FERC 61,288). That license was later surrendered by the potential developer due to the existing economic climate. In addition, the Commission affirmed its jurisdiction over hydropower projects located on the Outer Continental Shelf (OCS) in the subsequent case of Pacific Gas \& Electric Company (125 FERC 61,045), involving applications for two preliminary permits.

\section{Preliminary Permits vs. Licenses} The distinction between FERC preliminary permits and FERC licenses (and the authority they convey) can be misunderstood by those not familiar with the Commission's hydropower program. The sole purpose of a preliminary permit, which has a term of up to three years, is to give the permit holder priority of application for license during the permit term. If the permit holder files an acceptable license application with the Commission during the permit term, the Commission will entertain competing development applications, but will award the license to the permit holder if the permit holder's project proposal is, or can be made, equal or better adapted to develop, conserve, and utilize in the public interest the water resources of the region than those of any competing applications. A preliminary permit does not authorize entry upon any lands, any land-disturbing activities, or construction. A license, on the other hand, has a term of up to 50 years, and authorizes construction and operation.

\section{Strict Scrutiny Policy}

Because the sole purpose of a preliminary permit is to maintain priority for the permittee for any license application it subsequently files within the permit period, the Commission has historically issued such permits based on limited, preliminary information. To address concerns that this approach would allow developers within the new hydrokinetic industry to obtain permits for "site banking" purposes (i.e., to maintain priority over a site without any intention of developing it, rather than for the purpose of developing a license application), the Commission has established a "strict scrutiny" policy in issuing preliminary permits for hydrokinetic projects.

The "strict scrutiny" policy entails limiting the boundaries of issued permits and conducting closer scrutiny of semi-annual reports already required of permit holders to ensure progress toward developing a license application, and cancelling permits where sufficient progress is not shown. This policy aims to discourage site banking by providing a disincentive for developers to seek permits for projects that they are not ready to pursue, and, through the limiting of permit boundaries, to encourage more thoughtful development of preliminary permit applications. Once a preliminary permit has been issued, the policy requires permit holders seeking a commercial license to file a notice of intent (NOI) and preliminary application document (PAD) within the first year 
of the three-year permit term. Permit

holders seeking a pilot project license are required to file an NOI and draft license application within the first two years of the three-year permit term. A detailed description of the differences between a Commission-issued commercial and a pilot project license is provided below.

\section{COMMERCIAL PROJECTS}

Commercial licenses can carry a term of up to 50 years for original licenses and 30 to 50 years for succeeding licenses. The Commission has three licensing processes available to developers seeking a commercial license: the Integrated Licensing Process (ILP), the Traditional Licensing Process (TLP), and the Alternative Licensing Process (ALP). Each of these processes comprises prefiling and post-filing with specific process requirements for the periods leading up to, and following, the filing of a license application. The purpose of all of these
Environmental Policy Act (NEPA), and includes both pre- and post-filing process deadlines for applicants and stakeholders, as well as Commission staff. The goal of this process is to resolve all disputes about necessary studies before the filing of an application and to keep the proceeding on a timely schedule.

The TLP is primarily an applicantdriven process, typically with no direct Commission staff involvement in the pre-filing stage, but requiring consultation with all concerned parties, including resource agencies, Native American tribes, and the public. NEPA scoping typically occurs after a license application is filed under the TLP. The ALP is a more collaborative process, but unlike the ILP in which the Commission approves study plans, the Commission only has an advisory role in the pre-filing stage, during which studies are developed by a collaborative group of stakeholders through a cooperative scoping or ALP for proposed projects that have limited controversy, a well-established record of information, and where the time line requirements of the ILP may appear to be too restrictive.

Each of the Commission's licensing processes is structured to effectively weigh the concerns of the applicant, federal and state resource agencies, Native American tribes, and the public while complying with the mandates of applicable laws such as the FPA, NEPA, the Clean Water Act, the Coastal Zone Management Act, the Marine Mammal Protection Act, the Endangered Species Act, and the Ports and Waterways Safety Act.

Under the "comprehensive development" standard of FPA Section 10(a), the Commission has responsibility to license only those projects that it determines "will be best adapted to a comprehensive plan for improving or developing a waterway" and must consider all aspects of the public interest. Licensing decisions are made by the Commission after preparation of an environmental assessment or environmental impact statement in compliance with the Commission's regulations for implementing NEPA (18 C.F.R. $\$ \$ 380.1-380.11$ ). The NEPA document (environmental assessment or environmental impact statement) considers both adverse and beneficial environmental impacts, and balances environmental protection, mitigation, and enhancement with other project benefits if the Commission decides to license the project (FERC, 1991).

FPA Section 10(a) also requires the Commission to consider a project's consistency with federal and state comprehensive plans for improving, developing, or conserving waterways. Such plans may include a state 
restoration plan for a certain fish species, a management plan for a national forest, or any other federal or state agency plan that is filed with the Commission and accepted as a comprehensive plan. The Commission considers the consistency of a project with goals outlined in comprehensive plans and gives due weight to such plans in any licensing decision. If the Commission determines that a project would not comply, in whole or part, with any comprehensive plan, it must explain why the project should be licensed notwithstanding that noncompliance. For projects affecting tribal lands or waters, the appropriate tribe must be consulted and its concerns addressed.

FPA Section 10(j) requires the Commission to issue hydropower licenses that are consistent with recommendations pursuant to the Fish and Wildlife Coordination Act (16 U.S.C. $\$ \$$ 661-666c) if such recommendations are consistent with the FPA and other applicable law. The National Marine Fisheries Service, the US Fish and Wildlife Service, and state fish and wildlife agencies may make such recommendations.

Certain state and federal agencies have mandatory conditioning authorities that require the Commission to include conditions filed pursuant to their authority in any license issued, such as: (1) upstream and downstream fishway conditions that are appropriately prescribed pursuant to Section 18 of the FPA by the Secretary of the Interior or the Secretary of Commerce, (2) conditions filed under Section 4(e) of the FPA by the federal administering agency of lands that a proposed or existing project may occupy (e.g., US Forest Service, Department of the Interior, and US Army Corps of Engineers), and (3) conditions filed under Section 401 of the Clean Water Act (33 U.S.C. $\$ \$ 1251-$ 1376) by the delegated state agency, or agencies, for the state(s) in which any discharge from the hydropower project would be located.

The Endangered Species Act (16 U.S.C. $\$ \$ 1531-1544$ ) requires the Commission to consult with the Secretary of the Interior and the Secretary of Commerce on federally listed and proposed species and the designated and proposed critical habitat that may be affected by any licensing action taken (FERC, 2001). For projects affecting natural resources within a state's coastal zone, conditions may also be incorporated into licenses for compliance with the Coastal Zone Management Act (16 U.S.C. $\$ \$ 1451-1464)$.

\section{PILOT PROJECTS}

Due to the increased interest in hydrokinetic technologies and the lack of information regarding their potential environmental impacts, developers have been seeking ways to demonstrate the technical and financial feasibility of hydrokinetic technologies while gathering information on their environmental effects. One way to do this is through the deployment of small-scale, short-term demonstration, or pilot, projects.

\section{Verdant Policy}

The Commission, in order to facilitate these demonstration projects, has sought ways to accommodate them. An example of this is in what is now commonly referred to as the "Verdant Policy," in reference to Verdant Power, Inc., a permit holder who requested relief from the Commission's licensing requirements to test the environmental impacts and operational performance of six underwater turbines harnessing the tidal energy of New York's East River. The policy, issued in a declaratory order April 14, 2005 (111 FERC g 61,024, 112 FERC 61,143), determined that certain limited experimental deployments are permissible without a license from the Commission under the conditions that they are experimental in nature, are used for a short period for the purpose of conducting studies necessary to prepare a license application, and do not connect to, or displace power from, the interstate power grid.

\section{Pilot Project Licensing Process}

One of the concerns raised regarding the established Verdant Policy was that, while it allowed for the necessary evaluation of potential environmental impacts without a FERC license, it limited the ability of developers to recoup some of the costs associated with the development and testing of their new technologies. Although a FERC license would allow pilot projects to connect to the interstate power grid and generate income, many considered the Commission's existing licensing processes to be too time-consuming and expensive for small, temporary demonstration projects. A shorter, streamlined process was considered more appropriate due to the temporary and removable nature of pilot projects.

In response to these concerns, Commission staff developed guidance on how to streamline the Commission's ILP for licensing hydrokinetic pilot projects using an existing waiver provision within the ILP regulations. The resulting pilot project licensing guidance is tailored to meet the needs of entities interested in testing new technology, including connection with the interstate grid, while minimizing the risk of adverse environmental 


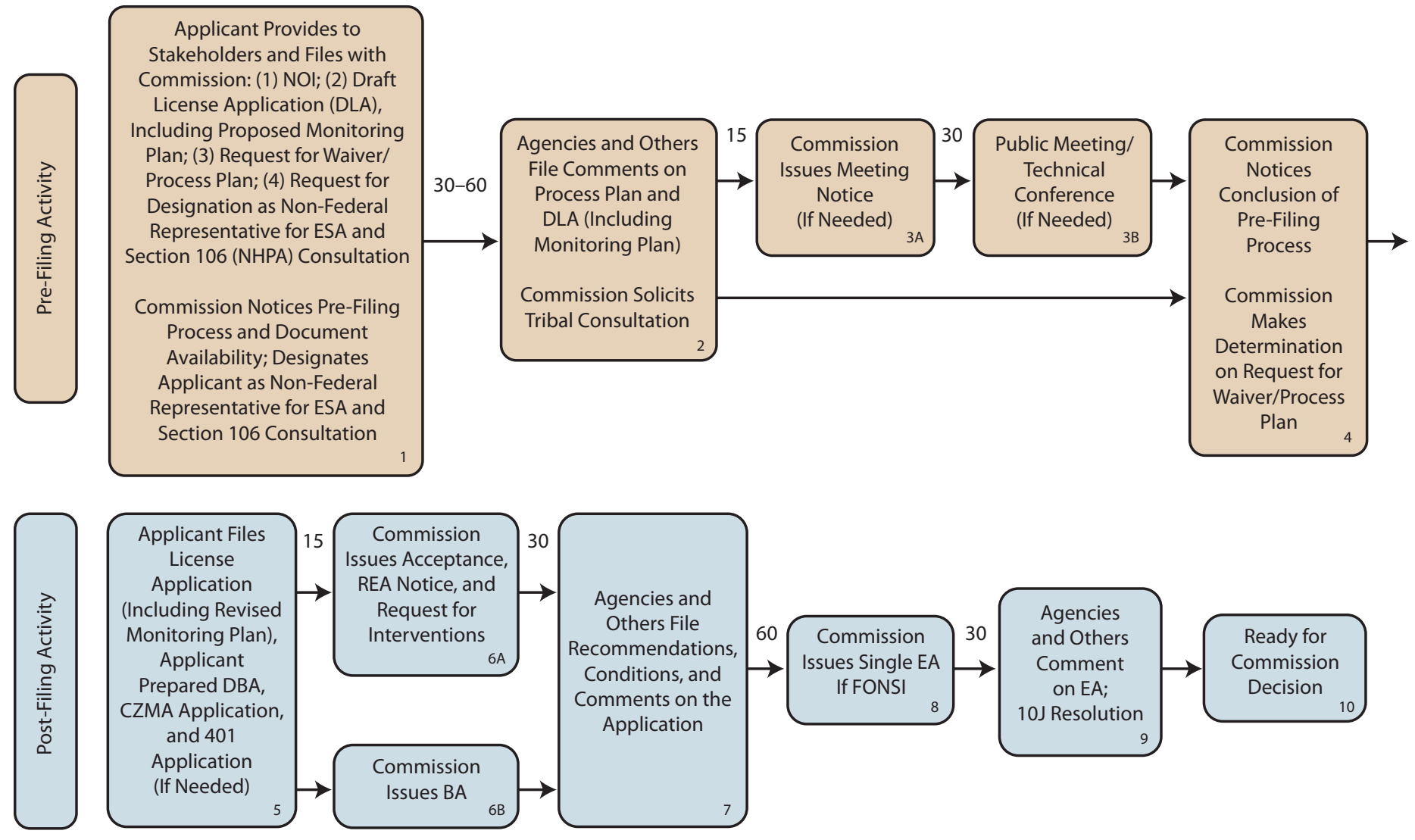

Figure 1. The Commission's Hydrokinetic Pilot Project licensing procedures.

impacts (Figure 1). The goal of the pilot project licensing guidance is to allow developers to test new technologies to determine appropriate sites for them, and, most importantly, to examine environmental effects, while providing for Commission oversight and agency input. The uncertainties surrounding potential environmental impacts of these new technologies are managed through a process that requires post-license monitoring and safeguard plans in any issued pilot project license. The process is intended to provide for completion of licensing in as few as six months.

The pilot project licensing process is available to small projects (typically with a generating capacity of $5 \mathrm{MW}$ or less) that are located in waters with no sensitive designations and are able to shut down on short notice and be removed, if necessary. Staff envisions these pilot licenses to have a short license term (five years), with the option of applying for a 30- to 50-year relicense at the end of the term. Staff anticipates including standard license conditions requiring project alteration or shutdown if monitoring reveals an unacceptable level of environmental effect, and decommissioning and site restoration when the license expires if the option for a full build-out license is not exercised. Detailed guidelines for this process are available on the Commission's Web site at http://www.ferc.gov.

\section{ADAPTIVE MANAGEMENT}

There are substantial uncertainties surrounding both the capabilities and potential environmental impacts of hydrokinetic technologies in the real world environment. The Commission supports the use of adaptive management strategies in the required monitoring and safeguard plans, as well as in the operation of the project, as a tool for managing these uncertainties. However, for adaptive management strategies to be included in an issued FERC license, the sidebars, or triggers and range of potential future modifications, must be understood and evaluated in the Commission's NEPA analysis for issuing the license. If there is a need for future modifications to any of the required measures or the project operation that were not evaluated in the Commission's NEPA analysis, the Commission may require the licensee to file a post-license amendment request for them, which, based on the type of modification being proposed, may require further NEPA analysis.

\section{STATUS OF HYDROKINETICS AND NEW INITIATIVES AT THE COMMISSION}

Currently, the Commission has issued 130 active preliminary permits for hydrokinetic projects (Table 1). Four 
Table 1. Summary of FERC-issued permits by location and technology (as of April 1, 2010).

\begin{tabular}{|c|c|c|}
\hline Tech & Location & $\begin{array}{l}\text { Number } \\
\text { of Issued } \\
\text { Permits }\end{array}$ \\
\hline \multirow{4}{*}{ Wave } & California & 7 \\
\hline & Hawai'i & 1 \\
\hline & Oregon & 1 \\
\hline & Washington & 1 \\
\hline \multirow{8}{*}{ Tidal } & Alaska & 2 \\
\hline & California & 1 \\
\hline & Delaware & 1 \\
\hline & Massachusetts & 2 \\
\hline & Maine & 6 \\
\hline & New Hampshire & 1 \\
\hline & New Jersey & 1 \\
\hline & New York & 3 \\
\hline \multirow{10}{*}{$\begin{array}{l}\text { Inland } \\
\text { River }\end{array}$} & Alaska & 4 \\
\hline & Arizona & 1 \\
\hline & Arkansas & 1 \\
\hline & Louisiana & 39 \\
\hline & Michigan & 4 \\
\hline & Missouri & 10 \\
\hline & Mississippi & 22 \\
\hline & Rhode Island & 1 \\
\hline & Tennessee & 12 \\
\hline & West Virginia & 9 \\
\hline \multicolumn{2}{|l|}{ TOTAL } & 130 \\
\hline
\end{tabular}

potential applicants are actively pursuing commercial licenses for their proposed hydrokinetic projects, all of which are in the pre-filing stages using either the Commission's TLP or ILP (P-12704, P-12713, P-12743, and P-12749). Eight draft license applications have been filed using the Commission's pilot project licensing process, two of which were dismissed due to inadequate consultation records. Of the remaining six proposed hydrokinetic pilot projects, five are still in the pre-filing stage (P-12665, P-12679, P-12680, P-12690, and P-12779), and one has completed pre-filing activities and plans to file a final license application with the Commission in 2010 (P-12611). On December 13, 2008, the Commission issued a license amendment to the existing City of Hastings Project (P-4306), a conventional hydropower project located on the Mississippi River in Hastings, Minnesota, that allowed for the deployment of two hydrokinetic turbines in the project's tailrace, providing an additional annual average generation of 364 megawatt-hours. The issued license amendment required monitoring and safeguard plans, as well as shut down and removal provisions based on monitoring results, similar to those that would be required in a pilot project license.

The Commission has recently been undertaking a number of initiatives relating to further improving the regulation of hydrokinetic projects. Staff is actively working with the states and various management agencies to better coordinate interagency programs for authorizing and consulting on hydrokinetic projects. This work has, to date, resulted in signed MOUs concerning such projects between the Commission and the coastal states of Oregon, Washington, and Maine; these MOUs are available on the Commission's Web site (http://www.ferc.gov). Finally, the Commission and MMS have been designated by the Department of Energy to act as co-chairs on its behalf for the International Energy Agency's (IEA's) Annex IV: Assessment of Environmental Effects and Monitoring Efforts for Ocean Wave, Tidal, and Current Energy Systems (Annex). The purpose of the Annex is to facilitate efficient government oversight of the development of ocean energy systems by expanding our baseline knowledge of environmental effects and monitoring methods. One of its primary goals is to ensure that existing information and data on environmental monitoring (and, to the extent possible, practices for environmental mitigation) are more widely accessible to those in the industry; national, state, and regional governments; and the public. To this end, the Annex will culminate in an accessible and searchable database of the assembled information and data that is available to the public.

\section{ACKNOWLEDGEMENTS}

Helpful input and reviews were provided by Ann Miles, Ed Abrams, Stephen Bowler, Merrill Hathaway, Elizabeth Molloy, David Turner, Kim Carter, and James Puglisi. The views expressed in this paper are those of the author and do not represent the official views and policies of the Federal Energy Regulatory Commission or any individual Commissioner. 迎

\section{REFERENCES}

Bedard, R.J., M. Previsic, and B.L. Polagye. 2009. Marine energy: How much development potential is there? Hydro Review 12(5), May 2009. Available online at: http:// www.renewableenergyworld.com/rea/ news/article/2009/04/marine-energy-howmuch-development-potential-is-yhere (accessed March 11, 2010).

FERC (Federal Energy Regulatory Commission). 1991. Evaluating relicense proposals at the Federal Energy Regulatory Commission. Federal Energy Regulatory Commission, Office of Hydropower Licensing (Paper DPR-2), Washington, DC.

FERC (Federal Energy Regulatory Commission). 2001. Hydropower licensing and endangered species: A guide for applicants, contractors, and staff. Federal Energy Regulatory Commission, Office of Hydropower Licensing, Washington, DC. 